\title{
Penyelesaian Sengketa Batas Daerah Menggunakan Pendekatan Regulasi
}

\author{
Saru Arifin \\ Fakultas Hukum Universitas Negeri Semarang \\ Kampus Sekaran, Gedung K Gunungpati Semarang Jawa Tengah 50229 \\ e-mail: saruarifin@mail.unnes.ac.id
}

\begin{abstract}
One of the increasing trends in the era of regional autonomy is the regional extension both at the provincial level and at districtcity level. However, such situation in some cases has emerged some new problems, such as: social conflict, conflict on natural resources and conflict in the regional boundaries. This study examines the problems; first, what factors are causing the dispute on the boundaries in the extension of new autonomous region? Second, how is the pattern of the settlement of boundary dispute provided in the Indonesian legal system? Third, what is the role of the Government in solving the boundary dispute? This is a juridical-empirical research. The study concluded that: First, the boundary dispute has been triggered by the area extension process not requiring the border as a legal requirement in the area expansion. The requirements fulfilled were more technical, physical and political. Second, the pattern of the boundary dispute resolution generally is through two ways: the non-legal border dispute resolution, and legal settlement. In non-legal resolution, it was mediated by MOHA and Governors; while, in the legal dispute resolution it reached through a judicial review to the Supreme Court or the Constitutional Court. Third, in the dispute of area border, the government's role was the facilitator in accordance with the level of its dispute case.
\end{abstract}

Keywords: Regional Boundaries, Boundary Dispute, the regional autonomy, government

\section{Abstrak}

Salah satu trend yang marak terjadi di era otonomi daerah adalah pemekaran wilayah baik di tingkat Provinsi maupun Kabupaten/Kota. Namun, situasi tersebut dalam beberapa kasus menimbulkan berbagai persoalan baru, seperti: konflik sosial, konflik sumber daya alam dan konflik batas-batas daerah. Penelitian ini mengkaji permasalahan, pertama, faktor-faktor apa yang menyebabkan timbulnya sengketa batas daerah dalam pemekaran daerah otonomi baru? Kedua, bagaimana pola penyelesaian sengketa batas daerah yang tersedia dalam sistem hukum Indonesia? Ketiga, bagaimana peran Pemerintah dalam penyelesaian sengketa batas daerah? Tipe penelitian yang dilakukan adalah yuridisempiris. Hasil penelitian menyimpulkan bahwa: Pertama, terjadinya sengketa perbatasan daerah dipicu oleh proses pemekaran daerah yang tidak mensyaratkan batas daerah sebagai syarat hukum dalam pemekaran daerah. Persyaratan yang dipenuhi lebih bersifat teknis, fisik dan politis. Kedua, pola penyelesaian sengketa batas daerah umumnya melalui dua jalur, yakni: penyelesaian sengketa batas daerah secara non hukum, dan penyelesaian secara hukum. Secara non hukum dimediasi oleh Kemendagri dan Gubernur. Sementara penyelesaian sengketa secara hukum ditempuh melalui judicial review ke Mahkamah Agung atau Mahkamah Konstitusi. Ketiga, dalam sengketa perbatasan daerah, peran pemerintah hanya sebagai fasilitator sesuai jenjang sengketa kasusnya.

Kata-kata kunci: Batas daerah, sengketa batas, otonomi dearah, pemerintah 


\section{Pendahuluan}

Laju perkembangan pemekaran wilayah yang sangat cepat selama dua belas tahun terakhir (1999-2012), berdampak pada bertambahnya jumlah pemerintah daerah di Indonesia. Di level Provinsi misalnya, terhitung lima provinsi baru lahir di negara ini, yaitu Sulawesi Barat, Banten, Bangka Belitung, Gorontalo, dan Kepulauan Riau. Pulau Papua yang sebelumnya merupakan sebuah provinsi pun, saat ini telah mengalami pemekaran, begitu pula dengan Kepulauan Maluku.

Pada awalnya pemekaran daerah didasarkan pada Undang-Undang Nomor 22 Tahun 1999 tentang Pemerintahan Daerah. Dalam ketentuan Pasal 5 ayat (2) disebutkan bahwa Daerah dapat dimekarkan mejadi lebih dari satu daerah. Namun, setelah UU Nomor 22 Tahun 1999 diganti dengan Undang-Undang Nomor 32 Tahun 2004 tentang Pemerintahan Daerah¹, ketentuan mengenai pemekaran wilayah tercantum pada Pasal 4 ayat (3) dan ayat (4), istilah yang dipakai adalah Pemekaran Daerah, yang berarti pengembangan dari satu daerah otonom menjadi dua atau lebih daerah otonom.

Dalam Pasal 4 ayat (3) UU Nomor 32 Tahun 2004 tersebut dinyatakan:" Pembentukan daerah dapat berupa penggabungan beberapa daerah atau bagian daerah yang bersandingan atau pemekaran dari satu daerah menjadi dua daerah atau lebih". Sedangkan dalam Pasal 4 ayat (4) undang-undang tersebut dinyatakan: "Pemekaran dari satu daerah menjadi 2 (dua) daerah atau lebih sebagaimana dimaksud pada ayat (3) dapat dilakukan setelah mencapai batas minimal usia penyelenggaraan pemerintahan".

Secara lebih khusus, Undang-Undang Nomor 32 Tahun 2004 mengatur ketentuan mengenai pembentukan daerah dalam Bab II tentang Pembentukan Daerah dan Kawasan Khusus. Dalam konteks itu, pemekaran wilayah juga termasuk dalam ruang lingkup pembentukan daerah. Undang-undang ini juga menentukan bahwa pembentukan suatu daerah harus ditetapkan dengan undangundang tersendiri. Ketentuan ini tercantum dalam Pasal 4 ayat (1). Kemudian, ayat (2) pasal yang sama menyebutkan bahwa: “Undang-undang pembentukan daerah sebagaimana dimaksud pada ayat (1) antara lain mencakup nama, cakupan

1 Perubahan terbaru terhadap undang-undang Pemda tersebut adalah UU No. 23 Tahun 2014 tentang Pemerintahan Daerah yang berlaku secara sah pada tanggal 2 Oktober 2014. 
wilayah, batas, ibukota, kewenangan menyelenggarakan urusan pemerintahan, penunjukan penjabat kepala daerah, pengisian keanggotaan DPRD, pengalihan kepegawaian, pendanaan, peralatan, dokumen, serta perangkat daerah."

Ketentuan normatif sebagaimana diatur dalam Pasal 4 ayat (2) UU Nomor 32 Tahun 2004 tersebut, pada prakteknya dilakukan secara makro, yakni hanya menyebutkan persyaratan kewilayahan yang hanya menyebutkan batas-batas wilayahnya saja. Kondisi ini pada tingkat operasionalnya menimbulkan persoalan demarkasi yang serius, yakni menyangkut titik-titik patok perbatasan daerah. Demarkasi merupakan langkah teknis dalam penentuan batas-batas wilayah yang ditandai dengan pemasangan patok dan sejenisnya².

Dalam beberapa penelitian sebelumnya terlihat, bahwa maraknya kasus sengketa batas wilayah tersebut dipicu oleh salah satunya ketidakjelasan batasbatas wilayah administratif antara daerah otonom baru dengan wilayah lama. Persoalan ini kemudian merambah ke berbagai konflik dimensional seperti konflik sosial dan konflik Sumber Daya Alam³.

Secara empiris, terdapat sejumlah kasus sengketa batas daerah baik yang diakibatkan pemekaran daerah otonom baru yang melibatkan daerah lama dengan daerah baru. Sebagai contoh, data dari Departemen Dalam Negeri (Depdagri) ${ }^{4}$, sebagaimana disampaikan oleh Kartiko ${ }^{5}$, menyebutkan bahwa sejak tahun 1999, dari 33 provinsi, baru 11 di antaranya yang menyelesaikan atau melaksanakan penegasan batas daerah dan baru 42 kabupaten/kota dari total 465 kabupaten/kota yang ada. Kartiko mengatakan, untuk provinsi yang melakukan

2 Prescott, V. dan Triggs, G.D., International Frontiers and Boundaries: Law, Politics and Geography, Martinus Nijhoff Publishers, 2008, hlm. 66.

3 Djoko Harmantyo. "Pemekaran Daerah dan Konflik Keruangan: Kebijakan Otonomi Daerah dan Implementasinya di Indonesia”, $M A K A R A$, SAINS, VOL. 11, No. 1, APRIL 2007: 16-22. Lihat juga beberapa kajian terkait seperti: Hasyim, Azis, Arya Hadi Dharmawan, dan Bambang Juanda, "Analisis Konflik Perebutan Wilayah di Provinsi Maluku Utara: Studi Kasus Perebutan Wilayah Antara Kabupaten Halmahera Barat dan Kabupaten Halmahera tentang Enam Desa”, Solidarity: Jurnal Transdisiplin Sosiologi, dan Ekologi Manusia, April 2010; Ucu Martanto, 2012. Ruang dan Konflik Wilayah: Cerita dari Enam Desa, CRCS UGM, Yogyakarta; Qodir, Zuly dan Tunjung Laksono, "Politik Rente dan Konflik di Daerah Pemekaran: Kasus Maluku Utara", Working Paper No. 002/JKSG/2012; dan Kristiyono, Nanang, Konflik Dalam Penegasan Batas Daerah Antara Kota Magelang dengan Kabupaten Magelang (Analisis Terhadap Faktor-faktor Penyebab dan Dampaknya), Tesis Program Magister Ilmu Politik, Pasca Sarjana UNDIP, Semarang, 2008.

${ }^{4}$ Saat ini menjadi Kementerian Dalam Negeri.

5 Antaranews.com, 22 September 2012. Kemendagri siap tangani sengketa tapal batas Sulbar, <http://www.antaranews.com/berita/334598/kemendagri-siap-tangani-sengketa-tapal-batas-sulbar>, diakses tanggal 23 September 2014. 
sengketa batas daerah ada 19 daerah dan 81 kabupaten/kota. Hal tersebut, biasanya disebabkan karena aspek yuridis yakni tidak jelasnya batas daerah dalam lampiran undang-undang dan peta lampiran undang-undang yang tidak memenuhi syarat sebagai peta.

Kemudian aspek ekonomi, karena perebutan sumber daya ekonomi, aspek kultural (isu terpisahnya etnis atau subetnis), aspek politik (berkaitan dengan perolehan suara bagi anggota DPRD atau jumlah pemilih), aspek sosial (munculnya kecemburuan sosial, isu penduduk asli dan pendatang). Faktor lainnya, bisa juga karena aspek pemerintahan, yakni adanya duplikasi pelayanan pemerintahan, seperti jarak ke pusat pemerintahan, atau isu ingin bergabung ke daerah tetangga. Saat ini menurut Kartiko terdapat sejumlah daerah yang bersengketa soal batas daerah di 19 daerah, yakni: di Jambi, Kepri, Kalsel, Kalteng, Kaltim, Riau, Sumut, Gorontalo, Sulteng, Sumsel, Irjabar, Malut, Sultra, Kep.Babel, Sulbar, Sumbar,Bengkulu, DKI, dan Banten ${ }^{6}$.

Diantara sekian konflik batas daerah tersebut, sebagian diantaranya berdampak pada timbulnya konflik lain seperti konflik sosial dan konflik sumber daya alam. Ironinya, hingga kini keinginan untuk memekarkan wilayah, mulai dari tingkat keluruhan/desa, kecamatan, kabupaten dan propinsi, masih terus bergulir. Alasannya pun sama yaitu untuk meningkatkan kesejahteraan rakyat dan memperpendek tali birokrasi?

Realitas tersebut selaras dengan hasil penelitian Qodir dan Laksono ${ }^{8}$, yang berhasil memetakan beberapa penyebab konflik terkait batas wilayah ini, antara lain: Yuridis: tidak jelasnya batas daerah dalam undang-undang Pembentukan Daerah; Ekonomi: Perebutan Sumber Daya (SDA, Kawasan Niaga/Transmigrasi, Perkebunan); Kultural: Isu terpisahnya etnis atau sub etnis; Politik \& Demografi: Perebutan pemilih \& perolehan suara bagi anggota DPRD/KDH; Sosial: Munculnya kecemburuan sosial, riwayat konflik masa lalu, isu penduduk asli dan

\footnotetext{
${ }^{6}$ Ibid.

Basomadiong, Pengaruh Pemekaran Wilayah Terhadap Konflik Sosial Masyarakat Lokal, dari http://basomadiong.wordpress.com/2012/12/25/pengaruh-pemekaran-wilayah-terhadap-konflik-sosialmasyarakat-lokal/, diakses tanggal 24 Februari 2014.

${ }^{8}$ Qodir dan Lasono, Op.Cit. hlm.27.
} 
pendatang; dan Pemerintahan: jarak ke pusat pemerintahan, diskriminasi pelayanan, keinginan bergabung ke daerah tetangga.

Dalam realitanya, sejumlah faktor tersebut ada yang secara kumulatif terjadi di dalam sebuah konflik batas daerah, namun juga ada yang hanya sebagian faktor penyebab saja. Penelitian yang dilakukan Martanto ${ }^{9}$ di Halmahera menunjukkan bahwa sengketa batas wilayah di daerah yang melibatkan 6 (enam) desa di Halmahera tersebut, dipicu oleh kontestasi ruang yang dilandasi oleh militansi sejarah akan eksistensi ruang wilayah yang sudah turun-temurun. Hadirnya politik pemekaran wilayah dianggap merusak situasi yang sudah berjalan secara harmoni dalam kurun waktu lama. Dalam konteks itu, konflik dipicu oleh persoalan kultural masyarakat setempat.

Kajian dengan lokasi yang sama dilakukan oleh Qodir dan Lakso ${ }^{10}$, menyimpulkan bahwa faktor pemicu timbulnya konflik batas daerah di wilayah tersebut juga dipicu oleh tiga faktor sekaligus, yakni SDM, SDA dan pemerintahan. Menurut hasil penelitian tersebut, pemekaran wilayah tidak didasarkan kepada kelayakan, sehingga baik secara SDM, SDA maupun finansial tidak terkelola dengan baik, sehingga menimbulkan kesemrawutan yang berdampak pada stagnasi pelayan publik dan kemunduran dalam sektor pembangunan daerah.

Sementara itu, dua tahu sebelum kedua kelompok peneliti sebelumnya melakukan penelitian, Hasyim, Dharmawan dan Juanda ${ }^{11}$, masih di lokasi yang sama melakukan penelitian dan menemukan hasil yang hampir serupa. Menurut hasil penelitian mereka, konflik keruangan daerah terjadi karena pemekaran hanya didasarkan pada pertimbangan politik yang lebih dominan. Sengketa batas wilayah dipicu oleh faktor politik, dimana pemekaran wilayah tidak didasarkan pada aspirasi masyarakat, sehingga menimbulkan kesenjangan administratif maupun kesejahteraan masyarakat di kedua daerah.

Terkait dengan berbagai penelitian tersebut, secara umum disimpulkan bahwa timbulnya berbagai konflik batas daerah selama ini karena dipicu oleh kebijakan pemekaran wilayah yang tidak terencana dengan baik. Jumlah daerah

\footnotetext{
${ }^{9}$ Martanto, Op. Cit. 13.

${ }^{10}$ Qodir dan Laksono, Loc. Cit.

${ }^{11}$ Hasyim, Dharmawan dan Juanda, Op. Cit., hlm. 31-32.
} 
pemekaran baru jauh melampaui batas ideal yang seharusnya sesuai dengan kondisi Indonesia. Namun, realitas yang ada menunjukkan bahwa pemekaran wilayah semakin berkembang secara pesat, sehingga menimbulkan dampak konflik teritori yang semakin banyak. Situasi ini, dalam beberapa kasus telah memicu terjadinya konflik sosial dan sumber daya alam, sehingga secara tidak langsung berdampak pada melemahnya ketahanan nasional ${ }^{12}$.

\section{Rumusan Masalah}

Berdasarkan deskripsi pada latar belakang di atas, maka dalam penelitian ini ada tiga permasalahan yang akan dianalisis. Pertama, apakah faktor yang menyebabkan terjadinya kasus sengketa batas daerah dalam pemekaran daerah di era otonomi? Kedua, bagaimana pola penyelesaian sengketa batas daerah yang tersedia dalam sistem hukum Indonesia? dan Ketiga, bagaimana peran Pemerintah dalam penyelesaian sengketa batas daerah?

\section{Tujuan Penelitian}

Penelitian ini bertujuan untuk: pertama, menganalisis dinamika politik hukum pemekaran wilayah yang dilakukan oleh pemerintah pusat (Kemendagri-DPR RI dan DPD RI). Hal ini dimaksudkan untuk mengetahui argumentasi yang dibangun dalam merumuskan norma-norma yang terkait dengan ketentuan persyaratan pemekaran wilayah, khususnya terkait dengan persoalan batas-batas wilayah. Kedua, penelitian ini bertujuan untuk menganalisis berbagai praktek pilihan penyelesaian sengketa batas wilayah yang telah dilakukan oleh para pihak yang bersengketa. Hal ini dimaksudkan untuk melihat efektifitas penggunaan suatu metode tertentu dan juga ketidakefektifan metode tertentu lainnya, sehingga masih belum bisa secara efektif menyelesaikan sengketa batas wilayah. Ketiga, menganalisis peran-peran apa saja yang dilakukan pemerintah selaku regulator dalam pemekaran wilayah dan khususnya terkait dengan sengketa batas wilayah yang ditimbulkan oleh pemekaran wilayah tersebut melalui instrumen perundangundangan, dalam hal ini undang-undang pemekaran wilayah.

12 Qodir, Zuly dan Tunjung Laksono, "Politik Rente dan Konflik di Daerah Pemekaran: Kasus Maluku Utara”, Working Paper No. 002/JKSG/2012, hlm.28. 


\section{Metode Penelitian}

Tipe penelitian yang dilakukan ini adalah yuridis-empiris, yaitu mengkaji permasalahan hukum dalam dimensi praktisnya dalam hubungan antar daerah otonom (lama dan baru), khususnya menyangkut masalah perbatasan daerah, dan dilengkapi dengan kajian terhadap peraturan perundang-undangan yang terkait dengan permasalahan penelitian sebagai berikut: 1. Undang-Undang Nomor 32 Tahun 2004 tentang Pemerintah Daerah; 2. Peraturan Pemerintah Nomor 78 Tahun 2007 tentang Tata Cara Pembentukan, Penghapusan, dan Penggabungan Daerah; 3. Peraturan Pemerintah Nomor 129 Tahun 2000 Tentang Tata Persyaratan Pembentukan, Penghapusan, dan Penggabungan Daerah; 4. Peraturan Menteri Dalam Negeri Nomor 1 Tahun 2006 tentang Pedoman Penegasan Batas Daerah; 5. Peraturan Menteri Dalam Negeri Nomor 27 Tahun 2006 tentang Penetapan dan Penegasan Batas Desa.

Sehubungan dengan tipe penelitian yang digunakan yakni yuridis-empiris, maka pendekatan yang dilakukan adalah pendekatan perundang-undangan (statute approach), pendekatan konsep (conceptual approach), dan pendekatan kasus (case approach)13. Data yang terkumpul, baik dari lapangan maupun data sekunder yang diperoleh dalam penelitian studi pustaka, aturan perundang-undangan, dan artikel ilmiah diuraikan dan dihubungkan secara sistematis guna menjawab permasalahan yang telah dirumuskan. Selanjutnya dilakukan dianalisis secara deskriptif-kualitatif untuk menghasilkan suatu kesimpulan dan rekomendasi penelitian $^{14}$.

\section{Hasil Penelitian dan Pembahasan}

Politik Hukum Pemekaran Daerah dan Implikasinya terhadap Sengketa batas Wilayah

Secara normatif pembentukan sebuah daerah otonom baru sebelum diputuskan secara formal melalui mekanisme politik di Dewan Perwakilan Rakyat yang diwujudkan dalam sebuah Undang-Undang yang bersifat spesifik, terdapat sejumlah tahapan kegiatan yang mesti dilalui. Tahapan-tahapan dimaksud

\footnotetext{
${ }_{13}$ Marzuki, Peter Mahmud, 2005, Penelitian Hukum, Prenada Media, Jakarta, hlm.39. Lihat Johnny Ibrahim, Teori \& Metodologi Penelitian Hukum Normatif, Bayumedia, Malang, 2006, hlm. 27.

${ }^{14}$ Ibid.
} 
sejatinya bersifat buttom-up dan demokratis. Hal itu ditandai dengan keharusan normative untuk mewadahi aspirasi masyarakat dari level yang paling bawah (masyarakat) sampai kepada elit-elit politik di Daerah. Ketentuan ini misalnya bisa dilihat dalam Pasal 14 PP Nomor 78 Tahun 2007.

Dalam pasal tersebut dinyatakan bahwa untuk mengusulkan sebuah daerah otonom baru harus dibuktikan dengan adanya dokumen aspirasi masyarakat yang diputuskan melalui Badan Permusyawaratan Desa (BPD). Keputusan tersebut kemudian disampaikan kepada DPRD setempat untuk dilegalkan menjadi keputusan DPRD, yang selanjutnya diajukan kepada Bupati/Wali Kota untuk diputuskan, apakah akan diterima atau ditolak. Keputusan Bupati/Wali Kota tersebut harus dilandasi oleh kajian terlebih dulu mengenai kelayakannya. Hasil dari proses ini kemudian dinaikkan ke tingkat provinsi untuk mendapatkan persetujuan yang ditandai dengan dikeluarkannya keputusan DPRD Provinsi. Selanjutnya, proses yang harus ditempuh adalah mengajukan usulan pemekaran daerah baru tersebut kepada Presiden melalui Menteri dengan melampirkan: 1. Hasil kajian daerah; 2. Peta wilayah calon provinsi; 3. Keputusan DPRD kabupaten/kota dan keputusan bupati/walikota sebagaimana; dan 4. Keputusan DPRD provinsi.

Pada tataran implementasinya, keempat persyaratan tersebut di sebagian daerah telah terpenuhi dengan baik, sebagian lagi tidak. Pada bagian berikut akan disampaikan data, bagaimana proses politik dalam pembentukan daerah otonom baru-yang dilakukan oleh Dewan Perwakilan Daerah RI, sebagai salah satu pihak yang berkompeten dalam proses pemekaran wilayah. Cukup banyak, usulan pemekaran daerah yang diproses oleh DPD bersama Dewan Perwakilan Rakyat Daerah.

Berdasarkan data dari Dirjen Otonomi Daerah, penambahan Daerah Otonom Baru sejak tahun 1999-2013 menunjukkan bahwa selama kurun waktu 14 tahun tersebut perjalanan otonomi daerah, telah melahirkan sebanyak 220 daerah otonom baru dengan rincian 8 Provinsi, 178 Kabupaten dan 34 Kota. Dari jumlah total tersebut sebagian ada yang dimekarkan dari inisiatif DPR RI yang paling dominan, sebagian peningkatan status dari kota administratif menjadi kota otonom, dan 
sebagian kecil peningkatan status dari kabupaten administratif menjadi kabupaten otonom.

Data tersebut juga menunjukkan bahwa Provinsi Sumatera Utara menempati posisi pertama dalam pemekaran wilayah yang mencapai 14 daerah otonom baru, disusul Aceh sebanyak 13 daerah otonom baru, dan Papua Barat sebanyak 11 daerah otonom baru. Sebaliknya, yang paling sedikit melakukan pemekaran adalah provinsi Jawa Timur yang hanya ada satu daerah otonomi baru, yakni Kota Baru yang dimekarkan dari Kabupaten Malang berdasarkan UU Nomor 11 Tahun 2001, disusul oleh Bengku sebanyak 2 daerah otonom baru dan Nusa Tenggara Barat sebanyak 3 daerah otonom baru.

Berdasarkan data tersebut, tampak Pulau Sumatera menempati posisi terbanyak dalam melakukan pemekaran daerah, disusul oleh Pulau Kalimantan, Pulau Sulawesi, Maluku, Papua dan Nusa Tenggara. Dari 34 Provinsi yang ada di Indonesia ${ }^{15}$, terdapat tiga provinsi yang tidak melakukan pemekaran, yakni Provinsi Jawa Tengah, DIY dan Bali.

Dalam perjalanan waktu, beberapa daerah yang memekarkan diri tersebut mengalami sengketa dengan daerah otonom baru. Persoalan yang terjadi dalam pemekaran daerah tidak hanya terjadi pada saat proses pemekaran daerah berlangsung, bahkan setelah pemekaran pun masih memunculkan persoalan salah satu diantaranya sengketa yang terkait dengan perbatasan antar daerah otonom yang berdampingan. Pemekaran daerah tidak dapat dilepaskan dari persoalan menarik garis batas wilayah. Penetapan garis batas antar dua daerah otonom memerlukan pertimbangan berbagai aspek agar tujuan desentralisasi dan otonomi daerah dapat tercapai. Salah satu aspek adalah konflik keruangan ${ }^{16}$.

Dalam konteks pemekaran daerah penetapan garis batas sudah dituangkan dalam UU tentang pembentukan suatu daerah. Namun yang menjadi pesoalan penentuan garis batas yang telah dituangkan dalam bentuk UU dalam implementasinya dilapangan masih memunculkan penafsiran dari masing-masing daerah yang berdampingan. Perbedaan penafsiran dari masing-masing pihak

${ }^{15}$ Data lengkap mengenai jumlah Provinsi dan Kabupaten di Indonesia sampai dengan tahun 2014 dapat dilihat dalam http://otda.kemendagri.go.id/images/file/data dan informasi/seputar_otda/total daerah otonom.pdf, 12 Februari 2012.

${ }^{16}$ Hermantyo, Op.Cit. hlm.18. 
inilah yang bermuara pada terjadinya sengketa perbatasan antar daerah. Dalam kenyataannya faktor pemicu terjadinya sengketa perbatasan dilatarbelakangi oleh berbagai motif. Hal tersebut akan diuraikan di bawah ini.

Hermen Batubara, menyebutkan ada beberapa faktor pemicu terjadinya sengketa perbatasan antara lain ${ }^{17}$ :

Ketidakjelasan UU Pembentukan Salah satu penyebab yang menonjol terdapat pada UU pembentukan Pemda, klausul tentang batas hanya disebutkan sebagai berbatasan dengan derah tetangganya. Misalnya disebelah utara berbatasan dengan daerah A; di sebelah selatan berbatasan dengan daerah B dan seterusnya. (sehingga muncullah perbedaan penafsiran antar UU, perbedaan pasal-pasal dengan peta lampiran, ketidakjelasan peta lampiran). Contoh: Sengketa Pulau Berhala antara Provinsi Kepri dan Provinsi Jambi.

Perebutan Sumber Daya Alam (SDA). Kalau di daerah itu ada sumber SDA maka batas bisa jadi rebutan. Masing-masing pihak biasanya akan berlomba melayani dan itulah awal sengketa. Contoh: Kab. Muba-Kab. Mura Prov Sumsel (Sumur Migas Subhan 4); Prov. Riau (Kab.Rohil)-Prov.Sumut (Kab.Labuan Batu) terkait patok 153 (perkebunan sawit); Prov.Aceh (Kab.Aceh Tamiang)-Prov.Sumut (Kab.Langkat) terkait potensi sarang burung walet di Goa Bukit Kapal.

Kesukuan/Kultur/Etnis. Meski batas hanya mengatur persoalan administrasi dan sama sekali tidak mempengaruhi masalah kepemilikan. Tetapi batas seolah sudah menjadi "pemisah" sehingga batas yang terdapat pada etnis yang sama; dinilai menjadi sebagai pemisah etnis itu sendiri. Contoh: Provinsi Sumatera Selatan (Kabupaten Musi Rawas)-Provinsi Jambi (Kab.Sorolangun) terkait eksistensi penduduk Suku Rawas.

Pelayanan Publik. Hal ini dimaksudkan untuk lebih mendekatkan pelayanan publik kepada warganya. Diharapkan warga yang ada di daerah batas tersebut lebih dekat dengan pusat-pusat pelayanan. Contoh: di Provinsi Bengkulu: keinginan penduduk sebag Desa di Kabupaten Kepahiang kembali bergabung ke Kab.Bengkulu Utara, Penduduk salah satu Kecamatan di Kutai Timur ver KTP Kota Bontang dan ingin bergabung ke Kota dengan alasan akses ke pusat pemerintahan lebih dekat (ke Sangata, Kutim 65 km; ke Kota Bontang hanya $3 \mathrm{~km})$.

Hal yang tidak jauh berbeda dengan apa yang diutarakan Hermen Batubara di atas, berdasarkan laporan dari Direktorat Jenderal Umum Kementerian Dalam Negeri18 adapun aspek yang berkaitan dengan pemicu munculnya sengketa batas daerah ada beberapa aspek. Misalnya, dalam aspek yuridis, sengketa terjadi

${ }^{17}$ Batubara, Harmen, Masalah Penyelesaian Sengketa Batas Antar Daerah, http://birokrasi.kompasiana.com/ 2012/ 02/22/masalah-penyelesaian-sengketa-batas-antar-daerah/, di akses 12 Februari 2012.

${ }^{18}$ Kementerian Dalam Negeri Direktorat Jenderal Pemerintahan Umum, Bahan Batas Daerah, Tidak dipublikasikan. 
dikarenakan tidak jelasnya batas daerah di dalam peta lampiran undang-undang pembentukan daerah yang bersangkutan, yang diperparah oleh lampiran peta yang tidak sesuai dengan kaidah-kaidah kartografis (seperti tidak ada skala dan koordinat), bahkan hanya berupa sketsa sehingga berdampak pada: 1. Overlapping cakupan wilayah; 2. Duplikasi pelayanan pemerintahan atau tidak adanya pelayanan pemerintahan; 3. Perebutan untuk mengelola sumber daya alam; 4. Overlapping perijinan lokasi usaha; dan 5. Daerah pemilihan ganda pada proses Pemilu dan Pemilukada; 6. Ketidaksinkronan antara pasal dalam batang tubuh Undang-Undang pembentukan daerah dengan batas yang dituangkan dalam peta yang sangat sederhana; 7. Ketidaksinkronan antara Undang-Undang pembentukan daerah yang satu dengan yang lain.

Sementara dalam aspek ekonomi sengketa berkaitan dengan perebutan sumberdaya ekonomi, baik menyangkut keberadaan sumberdaya alam yang ada di wilayah yang dipersengketakan maupun menyangkut potensi ekonomi di wilayah yang bersangkutan. Pada aspek kultural sengketa berkaitan dengan terpisahnya etnis atau sub etnis dengan adanya pemekaran. Sementara pada aspek politik sengketa berkaitan dengan aspek politik di daerah yang bersangkutan, seperti jumlah pemilih dan perolehan suara bagi anggota Legislatif dan juga Pilkada.

Dalam aspek sosial sengketa batas daerah berkaitan dengan kecemburuan sosial, isu pendatang dan penduduk asli, potensi/riwayat sengketa, yang erat kaitannya dengan aspek ekonomi, politik dan kultural. Sementara pada aspek pemerintahan sengketa batas daerah berkaitan dengan adanya duplikasi pelayanan pemerintahan, jarak ke pusat pelayanan pemerintahan, atau keinginan suatu wilayah untuk bergabung dengan/dilayani oleh pemerintah daerah yang berdekatan.

Menurut Heru Santoso19, terkait dengan faktor yang paling dominan penyebab terjadinya sengketa perbatasan daerah adalah: 1. Faktor yuridis, yakni undang-undang dan lampiran peta undang-undang tentang pembentukan yang

${ }^{19}$ Kepala Sub Direktorat Batas Daerah wilayah II, Wawancara, 9 November 2014. 
tidak jelas, sehingga di lapangan terjadi ketidak sepakatan; 2. Adanya tumpang tindih perizinan (Sumber Daya Alam).

Data ini menunjukkan bahwa ketidakjelasan batas daerah secara normatif telah memicu terjadinya penafsiran yang berbeda oleh masing-masing di lapangan oleh pemerintah daerah yang bersengketa. Hal ini tidak terlepas dari proses pembentukan daerah otonom baru yang nuansanya banyak dipengaruhi oleh kepentingan-kepentingan politik. Persoalan batas daerah tidak menjadi persyaratan mutlak yang harus dipenuhi sebelum disahkan menjadi Dearah Otonom Baru. Proses pemekaran daerah selama ini berjalan secara politis di DPR RI. DPD RI dan Kemendagri tidak diberikan ruang yang memadai dalam menyampaikan persoalan-persoalan terkait dengan pemekaran daerah tersebut. ${ }^{20}$

\section{Pola Penyelesaian Sengketa Batas Daerah}

Secara teoretis dan yuridis, pola penyelesaian sengketa batas wilayah dapat dilakukan melalui dua metode, yakni: metode non hukum melalui negosiasi dan mediasi atau bisa disebut juga dengan metode penyelsaian sengketa secara administratif; dan metode hukum, melalui sarana peradilan. Dalam prakteknya, metode penyelesaian sengketa batas daerah yang paling sering digunakan adalah metode administratif melalui fasilitasi kepala daerah dan kementerian dalam negeri sesuai dengan jenjang kasus sengketa perbatasan yang terjadi.

\section{Metode Penyelesaian Sengketa Non Hukum}

Penyelesaian sengketa batas daerah melalui metode non hukum, dilakukan melalui Negosiasi dan Mediasi.21 Penyelesaian sengketa batas daerah melalui metode ini bersifat administratif yang dilakukan di dalam lingkungan pemerintahan sendiri. Jika terjadi sengketa perbatasan antar daerah otonom di dalam satu provinsi maka penyelesaiannya difasilitasi oleh Gubernur. Namun dalam praktek Gubernur tidak memiliki kewenangan untuk menentukan status daerah yang disengketakan karena kewenangan tersebut berada di tangan pemerintah pusat melalui

${ }^{20}$ Wawancara dengan Heru Santoso Kepala Sub Direktorat Batas Daerah wilayah II, 8 November 2014; Muchammad Ilyas, Staff Pusat Kajian Daerah DPD RI, tanggal 17 Juni 2014.

${ }^{21} \mathrm{Hal}$ ini bisa dilihat dari ketentuan Pasal 198 UU No. 32 Tahun 2004 tentang Pemerintahan Dearah; Pasal 25 Permendagri No. 76 Tahun 2012 Tentang Pedoman Penegasan Batas Daerah; Permendagri Nomor 1 Tahun 2006 tentang Pedoman Penegasan Batas Daerah; dan Peraturan Pemerintah Nomor 19 Tahun 2010 tentang Tata Cara Pelaksanaan Tugas dan Wewenang Serta Kedudukan Keuangan Gubernur sebagai Wakil Pemerintah di Wilayah Provinsi. 
Kementerian Dalam Negeri dan posisi Gubernur hanyalah sebagai fasilitator untuk menyelesaikan sengketa yang terjadi antar daerah otonom ${ }^{22}$.

Adapun dasar hukum gubernur dalam menyelesaikan sengketa perbatasan antar daerah otonom adalah ketentuan Pasal 198 UU No. 32 Tahun 2004 yang menyatakan bahwa: (1) Apabila terjadi perselisihan dalam penyelenggaraan fungsi pemerintahan antar Kabupaten/kota dalam satu provinsi, Gubernur menyelesaikan perselisihan dimaksud; (2) Apabila terjadi perselisihan antar provinsi, antara provinsi dan Kabupaten/kota di wilayahnya, serta antara provinsi dan Kabupaten/kota di luar wilayahnya, Menteri Dalam Negeri menyelesaikan perselisihan dimaksud; (3) Keputusan sebagaimana dimaksud pada ayat (1) dan ayat (2) bersifat final.

Lebih lanjut dalam ketentuan Pasal 25 Peraturan Menteri Dalam Negeri Nomor 76 Tahun 2012 Tentang Pedoman Penegasan Batas Daerah, disebutkan bahwa: (1) Dalam hal terjadi perselisihan dalam penegasan batas daerah dilakukan penyelesaian perselisihan batas daerah; (2) Penyelesaian perselisihan batas daerah antar Kabupaten/kota dalam satu provinsi dilakukan oleh gubernur; (3) Penyelesaian perselisihan batas daerah antar provinsi, antara provinsi dengan Kabupaten/kota di wilayahnya, serta antar provinsi dan Kabupaten/kota di luar wilayahnya, dilakukan oleh Menteri Dalam Negeri.

Dalam ketentuan Permendagri Nomor 1 Tahun 2006 tentang Pedoman Penegasan Batas Daerah dinyatakan bahwa jika terjadi sengketa batas wilayah Kabupaten/Kota dalam satu Provinsi, maka penyelesaiannya di mediasi oleh Gubernur. Sebaliknya, jika terjadi sengketa batas wilayah dengan provinsi lain, maka di mediasi oleh Menteri Dalam Negeri.

Selain itu, menurut Peraturan Pemerintah Nomor 19 Tahun 2010 tentang Tata Cara Pelaksanaan Tugas dan Wewenang Serta Kedudukan Keuangan Gubernur sebagai Wakil Pemerintah di Wilayah Provinsi dinyatakan bahwa Gubernur dalam menyelesaikan perselisihan antar kabupaten/kota gubernur melakukan langkah persuasi dan negosiasi serta membangun kerjasama antar daerah. Saat ini, dasar 
hukum kewenangan gubernur dalam penyelesaian sengketa batas daerah adalah Peraturan Menteri Dalam Negeri Nomor 76 Tahun 2012.

\section{Penyelesaian Sengketa Batas Daerah Secara Hukum}

Penyelesaian sengketa batas daerah secara hukum dilakukan oleh Mahkamah Agung, Mahkamah Konstitusi dan Pengadilan Tata Usaha Negara. ${ }^{23}$ Berdasarkan data dari Kementerian Dalam Negeri, diketahui bahwa terdapat sebanyak 729 segmen batas wilayah daerah belum selesai dibenahi24. Secara prosedur, persoalan sengketa segmen batas wilayah yang terjadi antara kota/kabupaten harus ditangani pemerintah provinsi dan jika masalah batas wilayah antar provinsi diselesaikan pemerintah pusat. Kalaupun tidak ada kepastian, bisa diselesaikan di lembaga peradilan sehingga putusan dari lembaga peradilan bisa memberikan kepastian hukum.

\section{Penyelesaian Sengketa Batas Daerah Melalui Mahkamah Agung}

Mahkamah Agung merupakan cabang kekuasaan negara yang melaksanakan kekuasaan yudikatif. Hal ini secara tegas dinyatakan dalam ketentuan Pasal 24 ayat (2) UUD 1945 yang menyatakan "Kekuasaan kehakiman dilakukan oleh sebuah Mahkamah Agung dan badan peradilan yang berada di bawahnya dalam lingkungan peradilan umum, lingkungan peradilan agama, lingkungan peradilan militer, lingkungan peradilan tata usaha negara, dan oleh sebuah mahkamah konstitusi".

Dalam menjalankan kewenangannya tersebut, maka oleh Undang-Undang, Mahkamah Agung (MA) diberikan beberapa fungsi, yaitu, fungsi mengadili di tingkat kasasi, fungsi menguji setiap peraturan perundang-undangan di bawah undang-undang terhadap undang-undang dan mempunyai wewenang lainnya yang diberikan oleh undang-undang sesuai dengan ketentuan Pasal 24 A ayat (1) UUD 1945.

${ }^{23}$ Hal ini bisa dilihat dalam ketentuan Pasal 11 ayat (2) UU No. 4 Tahun 2004 Tentang Kekuasaan Kehakiman yang memberikan kewenangan bagi MA untuk menguji produk hukum di bawah UU. Sementara kewenangan MK dalam penyelesaian sengketa batas daerah didasarkan pada Pasal 1 ayat (3) UU No. 24 Tahun 2003 Tentang Mahkmah Konstitusi.

24Jurnas.com, 5 Juni 2014. 729 Segmen Sengketa Batas Belum Beres, <http://m.jurnas.com/news/136819/729Segmen-Sengketa-Batas-Belum-Beres-2014/1/Nasional/Politik-Keamanan/>, diakses tanggal 23 September 2014. 
Dalam kaitan dengan penyelesaian sengketa perbatasan antar daerah terkait erat dengan fungsi MA dalam menguji setiap peraturan perundang-undangan di bawah undang-undang terhadap undang-undang. Fungsi MA dalam menguji setiap peraturan perundang-undangan di bawah undang-undang terhadap undang-undang inilah yang dikenal dengan Hak Uji Materiil. Secara yuridis pengaturan hak uji materiil yang dilakukan oleh MA dapat dijumpai dalam ketentuan Pasal 26 UU No 14 Tahun 1970 yang berbunyi:

Mahkamah Agung berwenang untuk menyatakan tidak sah semua peraturanperaturan dari tingkat yang lebih rendah dari Undang-undang atas alasan bertentangan dengan peraturan perundang-undangan yang lebih tinggi.

Putusan tentang pernyataan tidak sahnya peraturan perundang-undangan tersebut dapat diambil berhubung dengan pemeriksaan dalam tingkat kasasi.

Ketentuan Pasal 26 UU No. 14 Tahun 1970 tersebut secara substansi dinyatakan juga dalam ketentuan Pasal 31 UU No. 14 Tahun 1985 yang berbunyi:

Mahkamah Agung mempunyai wewenang menguji secara materiil hanya terhadap peraturan perundang-undangan di bawah undang-undang.

Mahkamah Agung berwenang menyatakan tidak sah semua peraturan perundang-undangan dari tingkat yang lebih rendah daripada undangundang atas alasan bertentangan dengan peraturan perundang-undangan yang lebih tinggi.

Putusan tentang pernyataan tidak sahnya peraturan perundang-undangan tersebut dapat diambil berhubungan dengan pemeriksaan dalam tingkat kasasi.

Pelaksanaan ketentuan Pasal 31 UU No. 14 Tahun 1985 ini dijabarkan dalam ketentuan PERMA No. 1 Tahun 2004 tentang Hak Uji Materil. Dalam Perma tersebut dinyatakan bahwa pengajuan pengujian peraturan perundang-undangan di bawah UU bisa langsung ke MA. Dalam kaitan dengan penyelesaian sengketa perbatasan antar daerah, MA tidak masuk pada peristiwa kongkrit yang terkait dengan sengketa, namun MA lebih pada aspek pengujian terhadap Permendagri yang merupakan bentuk legal-formal dalam penegasan batas antar daerah yang selama ini sering dijadikan instrumen dalam penegasan batas daerah. Misalnya, Permendagri No. 60 Tahun 2011 yang menegaskan batas-batas daerah pada tiga segmen antara Kabupaten Minahasa dengan Kabupaten Minahasa Tenggara. Selain itu, dalam kasus perbatasan antara Kota Tangerang Selatan dengan 
Kabupaten Tangerang ditetapkan melalui Permendagri No. 5 Tahun 2012, serta Kota Tangerang dengan Kota Tangerang Selatan melalui Permendagri No 11 Tahun 2011. Oleh sebab itu, Mahkamah Agung dalam penyelesaian sengketa batas daerah hanya fokus kepada pengujian Permendagri yang dijadikan dasar penetapan batas daerah-dan dimintakan uji materil oleh pihak-pihak yang berkepentingan.

\section{Penyelesaian Sengketa Batas Daerah Melalui Mahkamah Konstitusi}

Ketentuan Pasal 24 ayat (2) UUD 1945 menyatakan "Kekuasaan kehakiman dilakukan oleh sebuah Mahkamah Agung dan badan peradilan yang berada di bawahnya dalam lingkungan peradilan umum, lingkungan peradilan agama, lingkungan peradilan militer, lingkungan peradilan tata usaha negara, dan oleh sebuah mahkamah konstitusi".

Berdasarkan ketentuan Pasal 24 ayat (2) UUD 1945 tersebut di atas secara eksplisit menyatakan bahwa Mahkamah Konstitusi merupakan pelaku kekuasaan kehakiman di samping Mahkamah Agung dan badan-badan peradilan yang ada di bawahnya. Berdasarkan kewenangan yang dimiliki MK sebagaimana diatur dalam UU No. 24 Tahun 2003 Tentang Mahkamah Konstitusi, maka pintu masuk dalam penyelesaian sengketa perbatasan antar daerah yakni melalui pintu pengujian undang-undang terhadap Undang-Undang Dasar.

Wewenang MK dalam melakukan pengujian undang-undang terhadap Undang-Undang Dasar ini merupakan upaya untuk menyeimbangkan antara demokrasi yang disimbolkan melalui lembaga DPR dengan nomokrasi yang disimbolkan melalui MK. Jika dulu keputusan-keputusan politik yang hegemonik selalu bisa dipaksakan atas nama demokrasi, sekarang keputusan lembaga demokrasi dapat dibatalkan oleh lembaga nomokrasi. Terdapat beberapa UU yang ditetapkan secara demokratis di DPR, tetapi dibatalkan oleh MK karena bertentangan dengan nomokrasi ${ }^{25}$.

Sejauh ini pengujian UU yang terkait dengan pembentukan daerah otonom yang diajukan ke Mahkamah Konstitusi dalam kaitannya dengan penyelesaian sengketa perbatasan daerah sampai dengan 2014 sudah ada 9 putusan²6. Dalam

\footnotetext{
${ }^{25}$ Moh. Mahfud, MD., Konstitusi dan Hukum dalam Kontroversi Isu, Rajawali Pers, Jakarta, 2010, hlm. 415.

${ }^{26}$ Kesembilan Putusan MK tersebut adalah sebagai berikut:
} 
putusan tersebut ada 5 putusan menyatakan permohonan pemohon tidak dapat diterima, 2 putusan menolak permohonan pemohon, 1 putusan menyatakan mengabulkan seluruh permohonan pemohon, sedangkan 1 putusan lagi menyatakan mengabulkan permohonan pemohon untuk sebagian.

Sementara pertimbangan MK menyatakan permohonan pemohon/para pemohon tidak dapat diterima (niet ontvankelijk verklaard), misalnya dalam Putusan No. 34/PUU-VI/2008 pengujian atas UU No. 36 Tahun 2003 tentang Pembentukan Kabupaten Samosir dan Serdang Bedagai, didasarkan pada alasan bahwa pemohon/para pemohon tidak memiliki kedudukan hukum (legal standing) dalam kaitannya dengan adanya kerugian terhadap hak-hak konstitusional warga negara. Dalam kasus tersebut, empat putusan menyatakan permohonan pemohon tidak dapat diterima (niet ontvankelijk verklaard), dengan pertimbangan bahwa pemohon yang mengajukan permohonan ke MK tidak memiliki Legal Standing27, dan oleh karena itu pula MK tidak mempertimbangkan lebih lanjut pokok permohonan yang dimohonkan.

Data tersebut menunjukkan bahwa kewenangan penyelesaian sengketa batas daerah di Mahkamah Konstitusi adalah tetap dalam koridor kewenangan

1. Putusan No. 010/PUU-1/2003 pengujian atas UU No 11 Tahun 2003 tentang Perubahan UU No 53 Tahun 1999 tentang Pembentukan Kabupaten Pelalawan, Rokan Hulu, Rokan Hilir, Siak, Karimun, Natuna, Kuantan Singingi, Kota Batam, dengan hasil menolak permohonan Pemohon untuk seluruhnya.

2. Putusan No. 016/PUU-III/2005 pengujian atas UU No 12 Tahun 2001 tentang Pembentukan Kota Singkawang, dengan hasil permohonan Pemohon tidak dapat diterima.

3. Putusan No. 3.4/PUU-VI/2008 pengujian atas UU No 36 Tahun 2003 tentang Pembentukan Kabupaten Samosir dan Serdang Bedagai, dengan dengan hasil permohonan Pemohon tidak dapat diterima (Niet ontvankelijk verkelaard)

4. Putusan No. 4. 26/PUU-VI/2008 pengujian atas UU No 2 Tahun 2003 tentang Pembentukan Kabupaten Tanah Bumbu dan Kabupaten Balangan, dengan hasil permohonan Pemohon tidak dapat diterima.

5. Putusan No. 5. 123/PUU-VII/2009 pengujian atas UU No 40 Tahun 2003 tentang Pembentukan Kabupaten Seram Bagian Timur, Kabupaten, Seram Bagian Barat, dan Kabupaten Aru, dengan hasil mengabulkan permohonan Para Pemohon Untuk seluruhnya.

6. Putusan No. 6. 127/PUU-VII/2009 pengujian atas UU No 56 Tahun 2008 tentang Pembentukan Kabupaten Tambrauw, dengan hasil mengabulkan Permohonan Para Pemohon untuk sebagian.

7. Putusan No. 7. 18/PUU-X/2012 UU No 10 Tahun 1999 tentang Pembentukan Kabupaten Daerah Tk II Bengkayang dan UU No 12 Tahun 2001 tentang Pembentukan Kota Singkawang, dengan hasil permohonan Pemohon tidak dapat diterima.

8. Putusan No. 8. 32/PUU-X/2012 pengujian atas UU No 31 Tahun 2003 tentang Pembentukan Kabupaten Lingga, dengan hasil menolak Permohonan Pemohon untuk seluruhnya.

9. Putusan No. 9. 47/PUU-X/2012 pengujian atas UU No 54 Tahun 1999 tentang Pembentukan Kabupaten Sorolangun, Kabupaten Tebo, Kabupaten Muaro Jambi, dan Kabupaten Tanjung Jabung Timur, dengan hasil permohonan Pemohon tidak dapat diterima.

${ }^{27}$ Mengenai persyaratan legal standing tersebut dapat dibaca dalam Jimly Assiddiqie, Hukum Acara Pengujian Undang-Undang, Sinar Grafika, Jakarta, 2010, hlm.45-72. 
Pengujian UU terhadap UUD 1945, sesuai dengan konteks kerugian konstitusional yang dimohonkan oleh pihak yang mengajukan pengujian.28

\section{Peran Pemerintah Dalam Penyelesaian Sengketa Batas Daerah}

Secara normatif, peran Pemerintah dalam penyelesaian sengketa batas wilayah diatur dalam ketentuan Pasal 198 UU Nomor 32 Tahun 2004 sebagai berikut: (1) Apabila terjadi perselisihan dalam penyelenggaraan fungsi pemerintahan antar kabupaten/kota dalam satu provinsi, Gubernur menyelesaikan perselisihan dimaksud; (2) Apabila terjadi perselisihan antarprovinsi, antara provinsi dan kabupaten/kota di wilayahnya, serta antara provinsi dan kabupaten/kota di luar wilayahnya, Menteri dalam Negeri menyelesaikan perselisihan dimaksud; (3) Keputusan sebagaimana dimaksud pada ayat (1) dan ayat (2) bersifat final.

Berdasarkan ketentuan Pasal 198 tersebut, tampak ada dua jenis jenjang Pemerintahan yang berperan dalam penyelesaian perselisihan dalam penyelenggaraan pemerintahan. Dalam konteks ini menurut Reydonnizar, termasuk persoalan sengketa perbatasan daerah. Artinya, bahwa dalam kasuskasus sengketa perbatasan antar kabupaten/kota yang menjadi "Hakimnya" adalah Gubernur. Sementara jika terjadi perselisihan antar Provinsi dan/atau Provinsi dengan kabupaten/Kota, maka yang menjadi "Hakimnya" adalah Menteri Dalam Negeri29.

Dalam praktek di lapangan, ternyata kewenangan Mendagri dalam memutus persoalan sengketa antara Provinsi tidaklah bersifat final. Misalnya, dalam kasus sengketa Pulau Berhala di Provinsi Jambi. Dalam kasus tersebut Menteri Dalam Negeri telah mengeluarkan Permendagri Nomor 44 tahun 2011 yang menyatakan bahwa Pulau Berhala masuk ke dalam wilayah Kabupaten Tanjung Jabung Timur, Provinsi Jambi. Keputusan tersebut ternyata dipersoalkan oleh Provinsi Riau melalui gugatan ke Mahkamah Agung yang dalam putusannya status Permendagri tersebut dicabut oleh Mahkamah Agung.

Data tersebut menunjukkan bahwa peran-peran yang dimainkan oleh Pemerintah dalam hal ini Kemendagri tidak cukup kuat dalam memutus perkara

28 Soeroso, F.L., "Memaknai Kecenderungan Penyelesaian Konflik Batas Wilayah ke Mahkamah Konstitusi” Jurnal Konstitusi, 9(3), 2012, hlm.9.

${ }^{29}$ Winarno, Hery H. Sengketa Wilayah (1): 600 kasus PR Kemendagri, dalam https://www.merdeka.com/ khas/sengketa-wilayah-1-600-kasus-pr-kemendagri.html, diakses tanggal 5 April 2014. 
sengketa batas antardaerah. Dalam konteks ini, maka penyelenggaraan otonomi daerah yang diperankan oleh pemerintah pusat lebih bersifat administratif dan fasilitator. Hal ini merupakan konsekuensi logis dari sifat otonomi daerah yang memberikan kebebasan bagi pemerintah daerah untuk mengembangkan daerahnya. Demikian pula di tingkat Provinsi, Gubernur sebagai "Hakim” dalam sengketa batas daerah, hanya bersifat fasilitator saja, karena tidak berwenang mengeluarkan surat keputusan produk hukum berupa Keputusan Gubernur Jawa Timur tentang sengketa batas wilayah dengan sifat yang lex spesialis ${ }^{30}$.

\section{Penutup}

Berdasarkan hasil penelitian ini, maka dapat disimpulkan sebagai berikut. Pertama, bahwa proses pemekaran daerah yang menghasilkan daerah otonom baru selama ini banyak dimotivasi oleh kepentingan politis dan ekonomis. Kepentingan politik tersebut terkait dengan pengisian jabatan-jabatan baru seperti bupati, wali kota dan gubernur, serta jabatan-jabatan lain di pemerintah daerah otonom baru nantinya. Sementara sisi ekonomis terkait dengan potensi sumber daya alam yang ada di daerah otonom baru tersebut, serta harapan mendapatkan alokasi dana DAU dan DAK serta dana-dana lainnya dalam pelaksanaan otonomi daerah. Kedua, terhadap kasus-kasus sengketa batas daerah, mekanisme penyelesaian sengketa yang digunakan melalui dua jalur, yakni: penyelesaian sengketa batas daerah secara non hukum, dan penyelesaian secara hukum. Secara non hukum disebut juga penyelesaian sengketa melalui administrasi kepemerintahan, dalam hal ini dimediasi oleh Kemendagri dan Gubernur. Sementara penyelesaian sengketa secara hukum ditempuh melalui judicial review dan gugatan yang diajukan oleh para pihak ke Mahkamah Agung atau Mahkamah Konstitusi. Ketiga, peran pemerintah dalam penyelesaian sengketa perbatasan daerah adalah sebagai fasilitator dalam konteks penyelidikan kasus yang disengketakan, serta sebagai mediator dalam negosiasi penyelesaian sengketa batas daerah.

30 Irvan, Z., 2013. Wewenang Gubernur Dalam Menerbitkan Surat Keputusan Nomor 188/113/Kpts/013/2012 Tentang Penyelesaian Perselisihan Batas Daerah Antara Kabupaten Blitar dan Kabupaten KedirI (Studi di Provinsi Jawa Timur). Jurnal Mahasiswa Fakultas Hukum, 1(2), Universitas Brawijaya, Malang, hlm.7. Lihat juga Laurens, A., "Sengketa Wilayah Perbatasan Gunung Kelud Antara Pemerintah Kabupaten Blitar Dengan Kabupaten Kediri Ditinjau dari Undang-Undang Nomor 32 Tahun 2004 Jo UndangUndang Nomor 12 Tahun 2008 Tentang Pemerintahan Daerah." Calyptra: Jurnal Ilmiah Mahasiswa Universitas Surabaya, 2(1) 2013..hlm.12. 
Mengingat tingginya kasus sengketa batas daerah sejak otonomi daerah bergulir pada 1999, maka sebaiknya ketentuan mengenai pemekaran daerah, memasukkan persyaratan batas-batas daerah dalam UU pemekaran daerah mutlak diperlukan, sehingga hal ini tidak menjadi persoalan di kemudian hari. Selain itu, dalam proses pembentukan daerah otonom baru dalam fase legislasi di DPR RI, baik DPD RI maupun Kemendagri daerah terkait diberikan peran partisipasi yang luas untuk memberikan pertimbangan.

\section{Daftar Pustaka}

\section{Buku}

Asshiddiqie, Jimly, Hukum Acara Pengujian Undang-Undang, Sinar Grafika, Jakarta, 2010.

Ibrahim, Johnny, Teori \& Metodologi Penelitian Hukum Normatif, Bayumedia, Malang, 2006.

Kementerian Dalam Negeri Direktorat Jenderal Pemerintahan Umum, Bahan Batas Daerah, Tidak dipublikasikan.

Mahfud MD., Moh., Konstitusi dan Hukum dalam Kontroversi Isu, Rajawali Pers, Jakarta, 2010.

Marzuki, Peter Mahmud, Penelitian Hukum, Prenada Media, Jakarta, 2005.

Prescott, V. dan Triggs, G.D. International Frontiers and Boundaries: Law, Politics and Geography, Martinus Nijhoff Publishers, 2008.

Ucu Martanto, Ruang dan Konflik Wilayah: Cerita dari Enam Desa, CRCS UGM, 2012, Yogyakarta.

\section{Artikel Jurnal}

Harmantyo Djoko, "Pemekaran Daerah dan Konflik Keruangan: Kebijakan Otonomi Daerah dan Implementasinya di Indonesia", MAKARA, SAINS, VOL. 11, No. 1, APRIL 2007.

Hasyim, Azis, Arya Hadi Dharmawan, dan Bambang Juanda, 2010. "Analisis Konflik Perebutan Wilayah di Provinsi Maluku Utara: Studi Kasus Perebutan Wilayah Antara Kabupaten Halmahera Barat dan Kabupaten Halmahera tentang Enam Desa", Solidarity: Jurnal Transdisiplin Sosiologi, dan Ekologi Manusia, April 2010.

Irvan, Z., Wewenang Gubernur Dalam Menerbitkan Surat Keputusan Nomor 188/113/Kpts/013/2012 Tentang Penyelesaian Perselisihan Batas Daerah Antara Kabupaten Blitar dan Kabupaten Kediri (Studi di Provinsi Jawa Timur). Jurnal Mahasiswa Fakultas Hukum, 1(2), Universitas Brawijaya, Malang, 2013. 
Laurens, A., “Sengketa Wilayah Perbatasan Gunung Kelud Antara Pemerintah Kabupaten Blitar Dengan Kabupaten Kediri Ditinjau dari Undang-Undang Nomor 32 Tahun 2004 Jo Undang-Undang Nomor 12 Tahun 2008 Tentang Pemerintahan Daerah", Calyptra: Jurnal Ilmiah Mahasiswa Universitas Surabaya, 2(1) 2013.

Soeroso, F.L., Memaknai Kecenderungan Penyelesaian Konflik Batas Wilayah ke Mahkamah Konstitusi. Jurnal Konstitusi, 9(3), 2012.

\section{Hasil Penelitian/ Tugas Akhir}

Kristiyono, Nanang, Konflik Dalam Penegasan Batas Daerah Antara Kota Magelang dengan Kabupaten Magelang (Analisis Terhadap Faktor-faktor Penyebab dan Dampaknya), Tesis Program Magister Ilmu Politik, Pasca Sarjana UNDIP, Semarang, 2008.

Qodir, Zuly dan Tunjung Laksono, "Politik Rente dan Konflik di Daerah Pemekaran: Kasus Maluku Utara”, Working Paper No. 002/JKSG/2012.

\section{Internet}

Antaranews.com, 22 September 2012. Kemendagri siap tangani sengketa tapal batas Sulbar, <http://www.antaranews.com/berita/334598/kemendagri-siaptangani-sengketa-tapal-batas-sulbar >, diakses tanggal 23 September 2014.

Basomadiong, Pengaruh Pemekaran Wilayah Terhadap Konflik Sosial Masyarakat Lokal, http:/ /basomadiong.wordpress.com/2012/12/25/pengaruh-pemekaranwilayah-terhadap-konflik-sosial-masyarakat-lokal/, diakses tanggal 24 Februari 2014.

Batubara, Harmen, Masalah Penyelesaian Sengketa Batas Antar Daerah, http:/ /birokrasi.kompasiana.com/2012/02/22/masalah-penyelesaiansengketa-batas-antar-daerah/, di akses 12 Februari 2012.

Jurnas.com, 5 Juni 2014. 729 Segmen Sengketa Batas Belum Beres, <http:// m.jurnas.com/news/136819/729-Segmen-Sengketa-Batas-Belum-Beres2014/1/Nasional/Politik-Keamanan/>, diakses tanggal 23 September 2014.

Winarno, Hery H. Sengketa Wilayah (1): 600 kasus PR Kemendagri, dalam https:/ / www.merdeka.com/khas/sengketa-wilayah-1-600-kasus-prkemendagri.html, diakses tanggal 5 April 2014.

http:/ / otda.kemendagri.go.id/images/file/data_dan_informasi/seputar_otda/t otal_daerah_otonom.pdf, 12 Februari 2012.

\section{Peraturan Perundang-undangan}

Undang-Undang Nomor 32 Tahun 2004 Tentang Pemerintah Daerah (Lembaran Negara Republik Indonesia Tahun 2004 Nomor 125, Tambahan Lembaran Negara Republik Indonesia Nomor 4437).

Undang-Undang Nomor 16 Tahun 2013 Tentang Pembentukan Kabupaten Musi Rawas Utara di Provinsi Sumatera Selatan (Lembaran Negara Republik 
Indonesia Tahun 2013 Nomor 112, Tambahan Lembaran Negara Republik Indonesia Nomor 5429).

Peraturan Pemerintah Nomor 78 Tahun 2007 Tentang Tata Cara Pembentukan, Penghapusan, dan Penggabungan Daerah

Peraturan Pemerintah Nomor 129 Tahun 2000 Tentang Tata Persyaratan Pembentukan, Penghapusan, dan Penggabungan Daerah.

Peraturan Menteri Dalam Negeri Nomor 1 Tahun 2006 Tentang Pedoman Penegasan Batas Daerah.

Peraturan Menteri Dalam Negeri Nomor 27 Tahun 2006 Tentang Penetapan dan Penegasan Batas Desa.

\section{Putusan Pengadilan}

Putusan No. 010/PUU-1/2003 pengujian atas UU No 11 Tahun 2003 tentang Perubahan UU No 53 Tahun 1999 tentang Pembentukan Kabupaten Pelalawan, Rokan Hulu, Rokan Hilir, Siak, Karimun, Natuna, Kuantan Singingi, Kota Batam, dengan hasil menolak permohonan Pemohon untuk seluruhnya.

Putusan No. 016/PUU-III/2005 pengujian atas UU No 12 Tahun 2001 tentang Pembentukan Kota Singkawang.

Putusan No. 4/PUU-VI/2008 pengujian atas UU No 36 Tahun 2003 tentang Pembentukan Kabupaten Samosir dan Serdang Bedagai.

Putusan No. 26/PUU-VI/2008 pengujian atas UU No 2 Tahun 2003 tentang Pembentukan Kabupaten Tanah Bumbu dan Kabupaten Balangan.

Putusan No. 123/PUU-VII/2009 pengujian atas UU No 40 Tahun 2003 tentang Pembentukan Kabupaten Seram Bagian Timur, Kabupaten, Seram Bagian Barat, dan Kabupaten Aru.

Putusan No.127/PUU-VII/2009 pengujian atas UU No 56 Tahun 2008 tentang Pembentukan Kabupaten Tambrauw.

Putusan No. 18/PUU-X/2012 UU No 10 Tahun 1999 tentang Pembentukan Kabupaten Daerah Tk II Bengkayang dan UU No 12 Tahun 2001 tentang Pembentukan Kota Singkawang.

Putusan No. 32/PUU-X/2012 pengujian atas UU No 31 Tahun 2003 tentang Pembentukan Kabupaten Lingga.

Putusan No. 47/PUU-X/2012 pengujian atas UU No 54 Tahun 1999 tentang Pembentukan Kabupaten Sorolangun, Kabupaten Tebo, Kabupaten Muaro Jambi, dan Kabupaten Tanjung Jabung Timur.

\section{Wawancara}

Heru Santoso Kepala Sub Direktorat Batas Daerah wilayah II.

Muchammad Ilyas, Staff Pusat Kajian Daerah DPD RI. 